\title{
Mekân Tasarlama Eylemi ve Eğitimine Karmaşıklık Te- orisi Üzerinden Çağdaş Bir Yaklaşım
}

\author{
Özge KANDEMiR*
}

Mekân Tasarlama Eylemi ve Eğitimine Karmaşıklık Teorisi Üzerinden Çağdaş Bir Yaklaşım

Özet

Bilinmelidir ki karmaşık, öngörülemeyen ve değerleri çoğulcu olan konularla uğraşan tasarımcılar, günümüzde rasyonel tasarım metotları yaratma ya da kullanma çabasından uzaklaşarak yeni sorgulama ortamları-araçları yakalama arayışı göstermektedir. Bu çerçevede çalışmanın amacı; genelde tasarlama, özelde ise mekân tasarlama eyleminin yükümlülüklerinin sorgulanarak mekân tasarımı eğitimine yönelik yeni-yeniden önem kazanan temel değerlerin ortaya konulmasıdır. Bu yönde Karmaşıklık Teorisi, mekân tasarımı eğitimi için "çağdaş bir yaklaşım" geliştirilmesinde önemli bulunarak değerlendirilecektir. Mekân tasarlama eyleminin özünün ya da altında yatan bilincin ilişkiler ağına dayalı olduğu görülmektedir. Bu öz ise görünmez ilişkilere olanak tanıyacak ve bu ilişkileri anlayacak bir sistem teorisi içermekte olup, tasarım eğitiminin, daha önce olduğundan farklı olarak daha karmaşık ve anti-rasyonel hale getirecek bir yaklaşım gerektirmektedir. Bu yaklaşım biçimini ise bütünleşik tasarım yaklaşımının karşılayabileceği görülmektedir.

Anahtar Kelimeler: Tasarım, Mekân Tasarımı, Mekân Tasarımı Eğitimi, Karmaşıklık Teorisi, Bütünleşik Tasarım.
Acontemporary Approach to Spatial Design and its Education Through Complexity Theory

Abstract

It should be known that today the designers, which have to deal with the issues that are complex, non-predictable and pluralistic in values, seek to new inquiry environments and tools by getting away from the effort to create or use rational design methods. In this context, the aim of this study is to reveal re-emerging values of spatial design education by means of questioning the responsibility of the act of design in general and the spatial design in particular. In this respect, the Theory of Complexity is seen important to develop a contemporary approach for spatial design education. It is seen that the essence of the spatial design or its consciousness based on the network of relationships. This essence includes a systems theory which allows and understands invisible relations. This theory offers an approach which would make design education be more complex and antirational unlike before. It is seen that the integrated design approach can meet this approach.

Key Words: Design, Spatial Design, Spatial Design Education, Complexity Theory, Integrated Design.

\section{Giriş}

Heskett (2002, s. 7) tasarımı, doğada örneği bulunmayan yollardan çevremizi biçimlendirip oluşturmaya, gereksinimlerimize hizmet etmeye ve yaşamlarımıza anlam katmaya yarayan ve

* Özge KANDEMiR, Dr.Öğr.Üyesi., Eskişehir Teknik Üniversitesi, i̇ç Mimarlık Bölümü, ozgekandemir@eskisehir.edu.tr; ORCID ID orcid.org / 0000-0001-7999-5845 
Özge KANDEMIR

gezegendeki başka hiçbir varlığın sahip olmadığı 'insana özgü' bir yetenek olarak tanımlarken, Mitcham (1995, s. 174) tasarımın, tarihsel olarak her zaman var olmadığını dile getirmiştir. Çünkü doğada tasarım süreci gerçekleşmemektedir. Modern bilime göre, doğa ya kör kararlılıkla ya da rastgele değişimle doğmaktadır. Papanek'in deyimiyle de; örüntü, düzen ve güzellik açısından zengin olan tüm doğal şablonlar, insanlığın karar verme sürecinin sonucu olmayıp tasarım tanımının ötesine geçmektedir (Papanek, 2004, s. 4). Tasarım araştırmaları alanı kapsamında gerçekleştirilen bu ve benzeri sorgulamalarda tasarımın; doğada kendiliğinden açığa çıkan bir eylem olarak ele alınmadığı, insan dışında var olan diğer canlılar tarafından gerçekleştirilmeyen insana özgü bir eylem olarak kavramsallaştırıldığı dikkat çekmektedir. Bu doğrultuda insana özgü olup insan için gerçekleştirilen bu eyleme yönelik yaklaşımın (kapsamı, amacı, hedefi, yöntemi vb.) tarihi süreçte toplumsal yaşamla birlikte değişimler geçirdiği, günümüzde de tasarım disiplini içerisinde var olan kişiler için farkında olunması gereken sorgulamalar ve yükümlülükler barındırdığı görülmektedir.

Temelde yaşanan toplumsal değişimler ve teknolojik gelişmeler, ele alınan konuların doğasını değiştirerek, tasarımcıların bu konularla başa çıkmada yeni yollar aramasına neden olmaktadır. Rodriguez ve Peralta'nın ifadesiyle, toplumsal değişim ve teknolojik gelişmeler; toplumun daha fazla birbirine bağlı hale gelmesine, yeni etkileşim ve örgütlenme biçimlerinin açığa çıkmasına ve yeni deneyimlere-var olma biçimlerine yol açtığı için tasarımcıların ilgilendiği konuların doğası ve onlarla başa çıkma yolları değişmektedir (Rodriguez vd. 2014, s. 2). Ele alınan sorunlar ise, eskiye göre daha çok sayıda ve karmaşık olup, çözümlerinin daha zor olmasının yanı sıra çok büyük bir hızla da değişmektedir. Bu durumda sorunlar August Heckscher'in tanımladığı gibi bir tutuma gereksinin göstermektedir: Olgunlaşan tüm insanlar, yaşamın yalın ve düzenlenmiş gibi göründüğü bir anlayıştan, karmaşık ve usa aykırı geldiği başka bir anlayışa geçmektedir (Venturi, 1991, s. 18). $\mathrm{Bu}$ yönde farklılık teorisi de, dünya ve toplumun giderek karmaşıklaştığına işaret etmektedir. Bunun tersi ise; indirgeme, egemen olmayı amaçlayan teorik, pratik stratejik ve ideolojik bir güç aracı olarak ortaya çıkmaktadır. Fark; yakın ve uzak olanı, burada ve orada, gerçek ve ütopyayı mümkün ve imkânsızı bağlantılı hale getirmenin bir yolunu oluşturmaktadır. Bu yüzden de Lefebvre'nin ifadesiyle, sadece söylem üreterek değil, aynı zamanda "farklı olarak" yaşadığımız "kayıtsızlık" topluluğuna karşı mücadele etmeliyiz (Lefebvre, 2000, s. 27).

Bu çerçevede genel olarak tasarımcıların gerçekte karmaşık, bulanık, öngörülemeyen ve değerleri çoğulcu olan konularla uğraştıklarının farkında olarak, rasyonel tasarım metotları yaratma ya da kullanma çabasından uzaklaşıp yeni sorgulama alanları, ortamları ve araçları yakalama arayışına girmesinin gerekli hale geldiği görülmektedir. Bu doğrultuda iki temel amaç için ele alınan çalışma, öncelikle tasarımcının tasarlama eyleminin yapısına yönelik farkındalığını artırmayı, bu doğrultuda da tasarlama eyleminin karmaşıklı̆ını farklı yönleriyle ortaya koymayı hedeflemektedir. Salingaros, karmaşıklığı gizlemenin tasarım hakkında gerçekten dürüst olmamak olduğunu dile getirmiştir (Salingaros, 2014, s. 18). Zamenopoulosa ve Alexiou, karmaşıkık ve tasarım arasındaki ilişkinin, dört farklı yaklaşım altında sınılandıılabilecek çeşitli şekillerde yorumlandığını, ancak kaçınılmaz olarak birçok çakışmanın var olduğuna dikkat çekmiştir. Kabaca karmaşıklık: tasarımı 
uygulamada veya tasarım süreçlerini ve ürünlerini anlama ve temsil etmede karşılaşılan bir problem; tasarım sistemlerinin ve artifaktlarının karakteristik bir özelliği; tasarım için bir metodoloji ve araç; tasarımın anlaşılması ve tanımlanması için bir teori olarak kavranmaktadır (Zamenopoulosa vd. 2005, s. 96).

Ele alınan çalışmada ise karmaşıklık öncelikle, tasarımın nesnel olduğu kadar öznel, rasyonel olduğu kadar irrasyonel, öngörülemez, esrarengiz ve de betimlenemez doğasının tasarımcı tarafından farkına varııması ve temelde daha büyük ve tutarı bir eylemi kapsadı̆ı̆ın keşfedilmesine yönelik değerlendirilmiştir. Bu doğrultuda genel olarak tasarım özelde ise mekân tasarımı için var olan karmaşıklığın ortaya konulması, günümüzde karmaşıklık teorisinin mekân tasarlama eylemi ve eğitimine ilişkin potansiyeller barındıran söylemlerinin, sorgulama ve açılımlarının dikkate değer bulunup, değerlendirilebilir olmasında gerekli görülmüştür. Bu doğrultuda çalışmada:

- Karmaşık-lık kavramına ilişkin giriş niteliğinde genel bir sorgulama yapılmış,

- Genel olarak tasarımda karmaşık-lık kavramının karşılıklarına yer verilmiş,

- Özelde ise mekân ve tasarımın karmaşık yapısına dikkat çekilmiştir.

Tarihi süreçte "karmaşık düşünce"nin Heraclitus, Descartes, Kant ve Hegel’de uzun zamandır var olduğu (Lefebvre, 2000, s. 51) görülürken; “karmaşıklık teorisi”nin günümüzde fizik bilimlerinden doğa bilimlerine, doğa bilimlerinden de giderek sosyal bilimlere yönelik çok farklı alanlarda değerlendirmeye alındığı gözlenmiştir. Bu noktada ele alınan çalışma, karmaşık-lık ve teorisinin tasarım disiplini için de giderek artan önemini ortaya koyarken, değişen toplumsal yaşama entegre bir biçimde var olması beklenen mekân tasarlama eylemi için barındırdığı açıımları açığa çıkarmayı amaçlamıştır. Bu doğrultuda mekân tasarımı ve eğitimi için karmaşıklık teorisinin sunduğu kavram ve açıımlara yer verilerek bir sorgulama ortamının yaratılması hedeflenmiştir. Bilinmektedir ki, Lefebvre'nin ifadesiyle, mekân kavramı; zihinsel olanla kültürel olanı, toplumsal olanla tarihsel olanı birbirine bağlayan karmaşık bir süreç oluşturmaktadır (Lefebvre, 2014, s. 25). Bu çerçevede ele alınan çalışmada toplumsal bir ürün olarak açığa çıkan mekânın, temelde bir şey ya da bir nesne olmayıp, soyut-somut şeyler arasındaki ilişkiler bütününden oluştuğunun karmaşıklık kavramı ve teorisi üzerinden yeni-yeniden fark edilebilir kılınması hedeflenmiştir.

Farklı bilim dalları ve alanlarda farklı yönleriyle ele alınan karmaşıklık teorisi, burada tasarım disiplini ve mekân tasarımının kapsamının ve dâhil olduğu sorunların belirlenmesine bu doğrultuda da tasarım eğitimine ilişkin çağdaş bir yaklaşım biçiminin oluşturulabilmesine yönelik, çoklu düşünme aracı ve ortamı olarak değerlendirilmiştir. Genel olarak tasarım eylemi özelde ise mekân tasarımının nesnel ya da rasyonel herhangi bir metodolojiye indirgenemeyen karmaşık bir yapıya sahip olduğunun günümüzde ortaya konulması gerekli görülmüş; karmaşıklık teorisi bu noktada önemli görülerek, hem sorunun tanımlanmasında hem de çözüme yönelik yaklaşım biçiminin belirlenmesinde yol gösterici bulunmuştur. Elde edilen literatür verileri doğrultusunda, tasarım eyleminin karmaşık yapısının tasarım problemlerinin temel problemini ortaya koyarken, karmaşık- 
Özge KANDEMIR

lık teorisinin bu problemin çözümüne yönelik çağdaş bir yaklaşım yakalanması için potansiyel kavramlar ve açılımlar taşıdığına dikkat çekilmiştir.

\section{Karmaşık-lık Kavramı}

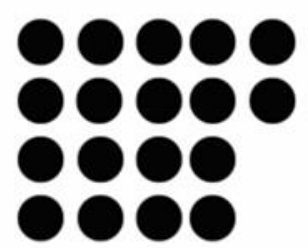

B a sit

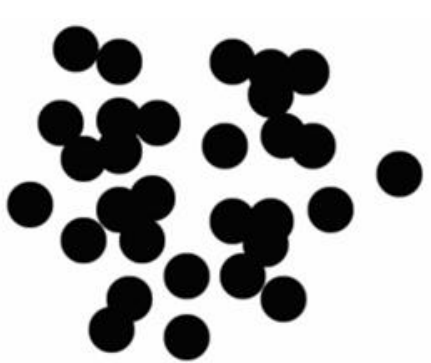

Karmaş $1 \mathrm{k}$

Şekil 1. Basit-Karmaşık ilişkisi ${ }^{1}$

Karmaşık ifadesi, içinde aynı cinsten birçok öge bulunan, birbirine az çok aykırı birçok şeyi içeren oluşumlara (TDK) yönelik bir sıfat olarak kullanılırken, Ruelle'nin deyimiyle, bir varlık eğer kolayIıkla elde edilemeyen bilgiler içeriyorsa karmaşık olarak nitelendirilmektedir (Ruelle, 2014, s. 181). Bu noktada Kolarevic karmaşık (complex) ve karışık (complicated) ifadelerinin birbirine karıştırılıp birbirlerini tanımlamada kullanıldıklarına dikkat çekmektedir. Merriam-Webster sözlüğüne göre, karmaşık "karışık veya birbiriyle ilişkili parçalardan oluşan bir bütün" anlamına gelmektedir; burada karmaşık ve karışık, tanım olarak eşanlamlı olarak kabul edilmektedir. Fakat eşanlamlı olma durumlarının tartışılması, daha sonra karmaşık ve karışık arasında bir ayrımın oluşmasına neden olmaktadır: buna göre karmaşık "gerekli bir birleştirmenin kaçınılmaz sonucunu önerir ve bir hata ya da başarısızlık anlamına gelmez. Buna karşın karışık; anlama, çözme ya da açıklamada büyük zorluklar gösteren şeylere yöneliktir. Bu çerçevede Clemens Bellut (2008), karmaşıklık kavramını felsefi bir perspektiften tartışırken, "karmaşık" ve "karışık" arasındaki ayrımı incelemektedir: Ona göre bir şeyin karışık olduğunu ifade etmek, "belirleyicilerinin sonlu sayısının doğrudan kavranamaması anlamına gelirken, buna karşın bir şeyin karmaşık olduğunu ifade etmek, belirleyicilerinin sayısının basitçe sınırsız olmasıdır. Aynı zamanda Clemens karmaşık olan bir şeyin, basitliğin görünümünü üstlenebilecekken karışık olanın her zaman basit olan her şeyi kendisinin dışında tuttuğunu gözlemlemektedir (Kolarevic, 2016, s. 26). Benzer bir biçimde Holland (2014) ve diğerleri de "karma-

${ }^{1}$ http://www.adamduvander.com/simple/how-simplicity-and-complexity-are-alike/ 
şık" ifadesini "karışık"dan ayırmaktadır. Sınırlar bulanıkken, "ortaya çıkış" karmaşık sistemleri karışık sistemlerin bir alt kümesi olarak ayırt etmektedir (Crawford, 2016, s. 2).

Herbert A Simon bu yönde karmaşık bir sistemin birbirleriyle basit olmayan bir etkileşim içerisinde bulunan çok sayıda parça içerdiğini dile getirmektedir (Venturi, 1991, s. 142). Kiel (1997, s. 1)'in ifadesiyle de karmaşık sistemler lineer olmayan ilişkilerin dinamik, kaotik ve öngörülemez elementleriyle tanımlanmaktadır. David Ng'ye göre ise karmaşık bir sistem, birbirine bağlı ve değişken kısımlardan oluşan işlevsel bir bütünü oluşturmaktadır. Başka bir deyişle, geleneksel bir sistemden (örneğin bir uçak) farklı olarak, parçaların sabit ilişkilere, sabit davranışlara veya sabit miktarlara sahip olması gerekmez; Böylece, bireysel işlevleri de geleneksel terimlerle tanımlanamayabilir. Bu kavramın görünürdeki zayıflı̆ına rağmen, bu sistemler dünyamızın çoğunu oluşturur ve birçok inorganik doğal sistemle (örneğin, nehirler) birlikte canlı organizmaları ve sosyal sistemleri içerir (David Ng, 2014, s. 7-8).

Karmaşık-lık ifadesinin ise, XX. yüzyılın son çeyreğinden buyana pozitivist bilimlerden sosyal bilimlere, bilişimden sanat-tasarım disiplinlerine geniş bir alanda konu edilerek farklı şekillerde tanımlanan bir terim haline geldiği dikkat çekmektedir. Allen (2001) genel olarak karmaşıklığı, çevresine sadece bir yönden değil, çok farklı yönlerden tepki gösterebilme kapasitesine sahip bir sistem olarak tanımlarken bu tanım, karmaşıkığın tek yönlü mekanik bir sistem olmadığı anlamına gelmektedir. Bu yönde Luhmann karmaşıklığ, bir sistemde gerçekleşme ihtimali olan çok sayıda olasılık olarak ele almaktadır (Luhmann, 1985, s. 25). Karmaşıklık, herhangi bir formalizmin, bütün özelliklerini ele geçirme yetisine sahip olmadığı gerçek bir dünya sisteminin özelliği olup (Mikulecky 2001, s. 344), yüksek düzeyde doğrusal olmayan bir etkileşim sergileyen çok sayıda varlıktan oluşan bir sisteme karşılık gelmektedir (Uden vd. 2001, s. 56). Karmaşıklık Salingaros'un deyimiyle, bir yapının karmaşıklığını, bir sistemin gerçekte nasıl çalıştığına yönelik kendi görünen makyajı altındaki saklı bilgiyi sunmaktadır. Bu iç karmaşıklık, sistemin "karmaşık" görünüp görünmediğinden bağımsızdır. Hiçbir yapısal bilgi içermeyen boş, aşırı düz bir şey karmaşık değildir. Bir sistem, onu çalıştırmak ya da yapısal olarak ayakta durmasını sağlamak için yeterli bir iç karmaşıkık olmaksızın var olamamaktadır (Salingaros, 2014, s. 18).

Bu noktada Simon karmaşık sistemlerin genel özelliklerini; çoklu bileşenler ve ilişkiler, kilitli geri bildirim döngüleri (bağımsız değişkenler ve doğrusal nedensellikten ziyade), yol bağımlılığı ve tahmin edilemezlik olarak karakterize etmektedir. Simon'un ifadesiyle, kabaca, karmaşık bir sistem, basit olmayan bir şekilde etkileşimde bulunan çok sayıda parçadan oluşan bir yapıya karşılık gelmektedir. Bu tür sistemlerde bütün, esasen metafiziksel anlamda değil, parçaların toplamından daha fazladır, fakat önemli bir biçimde pragmatik anlamda, parçaların özellikleri ve onların etkileşim kanunları göz önüne alındığında, bütünün özelliklerini ortaya çıkarmak için bu durum gerçekte önemsiz bir konu değildir. Karmaşıklık karşısında, ilkesel bir indirgemeci aynı zamanda pragmatik bir holist olabilmektedir (Simon, 1962, s. 468). Doğru bir biçimde görülen karmaşıklı̆ın sadece basitlik için bir maske olduğunu dile getiren Simon’a göre doğa bilimlerinin merkezi görevi, görünür kaos içindeki gizli örüntüyü bulmaktır. Harika, maskesiz, gizli örüntüyü açıklarken karmaşıklığın basitlikten nasıl bağımsız örüldüğüne yönelik yeni bir merak doğmaktadır. Doğal bilimin ve mate- 
Özge KANDEMIR

matiğin estetiği, kısmen gizli bir örüntünün keşfinde, müzik ve resim estetiği ile bir aradadır (Simon, 1996, s. 1-2). Sala (2004, s. 2)'nın ifadesiyle de karmaşıklık, doğal ve insan yapımı sistemlerde olduğu kadar meteorolojik sistemlerde, insanlarda ve sosyal yapılarda ortaya çıkabilmektedir. Karmaşıkık "kaosun kenarı" olarak da adlandırılabilirken... estetik bir duyuma da ilham verebilmektedir. Aslında, 1930'larda matematikçi George Birkhoff, şu şekilde tanımlanmış bir güzellik ölçüsü önermiştir: ( $\mathrm{M}=\mathrm{O} / \mathrm{C}$ ). Burada $\mathrm{M}$, “estetik ölçü" (veya güzellik) anlamına gelir, $\mathrm{O}$ düzen ve $\mathrm{C}$ ise karmaşıklık anlamına gelir. Bu ölçü, güzelliğin düzen ve karmaşıklıkla ilgili bir şey olduğu fikrini ortaya koymaktadır.

\section{Tasarımda Karmaşık-lık}

Bir sözcük olarak tasarım, birçok uyuşmazlığa konudur; sayısız belirtisi bulunurken, açıklık ile kesinlik sağlayan sınır çizgileri taşımamaktadır. Tasarım o kadar çok anlam basamağına sahiptir ki bu bile tek başına bir karmaşa kaynağı yaratmaktadır. Karışıklı̆ın derinleşmesi ise tasarım pratiğinin ve terminolojisinin geniş bir alana yayılmasından kaynaklanmaktadır (Heskett, 2002, s. 10-13). Ele alınan çalışma, tasarımda var olan bu çok yönlü karmaşıklığı, tasarımcı tarafından bütünleşik özgün-yaratıcı yolların yakalanmasında farkına varılması gereken bir potansiyel olarak görüp değerlendirmektedir. Venturi, "karmaşıklık yok olunca sadelik yavanlığa dönüşür" (Venturi, 1991, s. 19) uyarısında bulunurken, Lefebvre'nin "anlam ne kadar belirginleşirse, yaratıc kapasite, icat, hayal gücünün o kadar az söz konusu edilip; sadece emekten bahsedilir hale gelindiğini” (Lefebvre, 2014, s. 96) belirtmesi, tasarım kavramı ve eylemi için de önemli görülüp, tasarımda var olan karmaşıklık irdelemeye değer bulunmaktadır. Papenek'in deyimiyle daha mukavim bir tasarım düşüncesinin, ürünü (veya aracı veya ulaşım cihazını, binayı veya şehri), insan ile çevresi arasında doğrusal bir bağlantı olarak görmektedir. Gerçekte ise, insanı, araçlarını ve çevresini planlamaya, kendini ve çevresini manipüle etmeye yönelik düşünce biçimini; doğrusal olmayan, eşzamanlı, bütünleşik, kapsamlı bir bütün olarak düşünmek gerekmektedir (Papanek, 2004, s. 293). Oysaki doğrusal/çizgisel tasarım düşüncesi modeli, belirgin koşulları olan belirli sorunlara dayanmaktayken, burada tasarımcının görevinin tek tek söz konusu koşulları saptamaya ve ardından bir çözüm yolu bulmaya yönelik olduğu görülmektedir (Buchanan, 1992, s. 15-16). Bu noktada karmaşıklık, tasarım düşüncesinin gerçekte sahip olduğu değerleri tasarımcının yeni-yeniden farkına varmasını sağlayabilecek bir yaklaşım biçimi olarak görülmektedir.

Tasarımın, 'karmaşık bir toplumsal faaliyet' (Hardt, 2006) olup, terim olarak etkinliklerini ve sonuçlarını belirleyen pek çok tanım ve açıklama içerdiği (Irbite, 2014, s. 412) bilinmektedir. Bayazıt, günümüzde karmaşıklaşan tasarım sorunlarını çözmek ve kullanıcı ihtiyaçlarını karşılayabilmek amacıyla, tasarlama olgusuna, bir problem çözme ve karar verme eylemi olarak bakılmaya başlandığını belirtirken (Bayazıt, 2004, s. 51) Rodriguez L. ve Peralta, bir problem çözme faaliyeti olarak nitelendirilen tasarım sürecinin, problem çözme (problem-solving) yaklaşımı tarafından tanımlandığını dile getirmektedir. Problem çözümü, tasarım faaliyetinin ana sürücüsü olarak görülmektedir. Tasarımcılar genel olarak "sorunlar" olarak nitelendirilen olaylara tepki olarak ürünler geliştirmeye meyillidir... Fakat problem çözme yaklaşımı, kullanılmayan bir tasarım modeli ile ilişkili görünmek- 
tedir. Bir yandan, bu yaklaşım, insanların ihtiyaç ve arzuları hakkında iyi bir bilgi birikimi edinilmesi yoluyla problemlerin iyi tanımlanıp çözülebileceğine, diğer yandan da tasarımcının bunları tanıma yeteneğine sahip olduğu varsayımına dayanmaktadır. "Insanlar için iyi" nedir? Bu da tasarımı; tasarımcıların neredeyse sadece kendi ilgilendikleri konuları, kendi anlayışlarıyla yönlendirdikleri bir etkinlik haline getirmektedir. Bununla birlikte, katılımcı tasarım yöntemleri yoluyla kullanıcı katılımı giderek standart bir uygulama haline gelmektedir. Bunun sonucunda, 60'lı ve 70'li yıllardan sibernetik düşünceye dayanan tasarım yöntemleri hareketinden gelen problem çözme yaklaşımı modelinin, tasarım fikriyle de çakışır hale geldiği görülmektedir (Rodriguez vd. 2014, s. 2).

Bu çerçevede problem çözmeye yönelik benimsenen çizgisel modelin birçok çeşitlemesi olsa da bu modelin savunucuları, temelde tasarım sürecinin sorun tanımı ve sorun çözümü olmak üzere iki ayrı aşamaya ayrıldığını iddia etmektedir. Sorun tanımı, analitik bir silsiledir: Bu dilimde tasarımcı sorunun tüm öğelerini belirler ve başarılı bir tasarım çözümünün içereceği tüm gereklilikleri bir bir saptamaktadır. Sorun çözümü ise sentetik bir dilimdir: Bu dilimde çeşitli gereklilikler bir araya getirilip birbirlerine karşı bir dengeye konur, bunun sonucundaysa üretime taşınacak nihai bir plan ortaya çıkarılır... Fakat bazı eleştirmenler buradaki iki bariz zayıf noktaya işaret etmekte gecikmemiştir: Birincisi, uygulamadaki tasarım düşüncesi ve karar verme dilimi basit bir çizgisel süreç değildir; ve ikincisi, tasarımcıların üzerinde çalıştığı sorunlar, gerçek pratikte, şu ana dek ortaya konulmuş herhangi bir çizgisel analiz ve sentezle çözülememektedir (Buchanan, 1992, s. 15).

Tasarım ve diğer zor problem çözme eylemleri temelde keşif anları tarafından noktalanmaktadır. Bunlar, belirgin bir hazırlık yapılmaksızın çözüm girişimi sırasında önemli bir rol oynayan yeni bilgilerin ani ortaya çıkışı olarak tanımlanabilir. Bunlar, yeni ve önemli bir şeyin "aniden görüldüğü" anlardır (Kant, et al., 1984, s. 109). Dolayısıyla da tasarım bilgisi karmaşık, örülü, anlaşılması ve açıklanması zor bir bilgi olarak kavranmaktadır. Yurtsever'e göre bu bilgi, tasarımın tanımlanış biçimlerine göre kendine bir yol belirlemektedir. Iki farklı yaklaşımın sonucu olarak farklı anlayışlar ortaya çıkmaktadır. Bu iki farklı yaklaşımın biri tasarımı sezgisel bir süreç olarak, diğeri ise daha teknikle ve formüllerle ilerlemekte olan bir ürün olarak görmektedir. Bütüncül bir bakış açısı ile yaklaşıldığında, her ikisinin de tasarım süreci boyunca iç içe geçerek, deneyimle beraber tasarım bilgisini oluşturduğu söylenebilmektedir (Yurtsever, 2017, s. 387). Mimari tasarım bilgisi de nesnel olarak, öznelerarasılığın yarattığı ortaklaşalıklar, nesnellikler, evrensellikler ve tikel olarak öznenin kendi içselleştirmelerine dayalı durum ve süreçlerde belirmektedir. Mimari tasarım bilgisi, bütünün deneyimlenmesi ile içselleştirilir. Mimari tasarımda nesnel ya da öznel bilgi; mimari bütünün olumlanması, kabul edilmesi, yasalaşması ve uç noktada olumlanarak evrenselleşmesi ya da olumsuzlanması, göreceli olarak kabul edilmemesi ve uç noktada hiçleşmesi döngüsünde sonsuz olarak tekrar tekrar ele alınması ile oluşmaktadır (Sayın vd. 2009, s. 70).

Bu noktada Crilly'nin ifadesiyle birçok yaratıcılık araştırması da, sanatçıların ve bilim insanlarının çalışmalarını her ikisinde de ortak olan bilişsel süreçleri ortaya çıkarmak için incelemektedir. Bu tür çalışmalar nadiren tasarıma değinmezken, tasarımı hem sanatsal yaratıclık hem de bilimsel bir keşif, bir problem çözme eylemi olarak değerlendirebilmektedir. Bu çerçevede keşfetme ve yaratma eylemlerinin, sorunlara ilişkin çözümlerin keşfedilmesini gerektirdiği ve nispeten sınırlanmamış 


\section{Özge KANDEMIR}

sorunlara çözümler oluşturmaya yönelik olduğu ifade edilmektedir. Bu perspektiften, yaratıcı eylemlerin doğası tanımlanamamaktadır. Çözüm alanının ne kadar sıkı bağlandığı ve hangi faktörlerin bu sınırı (ör. Kültürel, ekonomik, fiziksel) belirleyerek yönlendirildiği, alanlar (örneğin, sanat, teknoloji, bilim) tarafından değerlendirilmektedir (Crilly, 2010, s. 57-58). Fakat Kwinter, bugün bile tasarımın içinde çok az kişinin, problemlerin bizim alanımızda nasıl formüle edildiğinin, nasıl oluşturulduğunun ve hangi güçlerin ve gelişmelerin onu oluşturduğunun farkında olduğunu dile getirmiştir (Kwinter, 2013, s. 313). Bu noktada gerçekte tasarımcıların karmaşık, bulanık, öngörülemeyen ve değerleri çoğulcu olan konularla uğraşmak zorunda olduğunu dile getiren Jonas (1996, s. 242), artık "gerçek" ihtiyaçlar ya da problemlere "gerçek" çözümler olmadığına da dikkat çekmektedir. Sorunlar pek çok alanda birbirine yakından bağlıdır. Toplumu, işlevsel olarak farklılaşmış, çoğunlukla kendi kendini organize eden bir sistem olarak görmek, aydınlatılmış ve genişlemiş bir akılcılık kavramına yönelik değerlendirmeleri gerektirir; bu da, ekonomik olmayan ve ölçülebilir olmayan uygulamaların yeniden ele alınmasını sağlamaktadır. Bu noktada Jonas'ın söylemiyle: tasarımın yükümlülükleri, neredeyse mesleki konulardan, eski yaklaşımların artık tatmin edici görülmediği tanımlanmamış problemlere (ill-defined) dönüşmüştür. Bu durum, 90'larda tasarımda ihtiyaçların kamçılanması yoluyla ihtiyaçların karşılanmasından, ihtiyaçların tatmin edilmesi / kamçılanması / müzakere etmesinin karmaşık karışımına doğru yönelen fonksiyonel değişimden kaynaklanmaktadır.

Tablo 1. Problemler Tipolojisi²

\begin{tabular}{|c|c|c|c|}
\hline \multicolumn{4}{|c|}{ P R O B L E M L E R } \\
\hline & Basit (simple) & Karmaşık (Complex) & Kötü Huylu (Wicked) \\
\hline Özet & Açık sorunlarla açık çözümler & $\begin{array}{l}\text { Açık olmayan problemler ve } \\
\text { çözümlerin zamanla } \\
\text { anlașllabilirliği }\end{array}$ & $\begin{array}{l}\text { Problem ve çözümlerin } \\
\text { anlaşılmazlığı ve tanımlanma } \\
\text { çabasında kaymaya devam } \\
\text { etmesi }\end{array}$ \\
\hline Özellik & $\begin{array}{l}\text { Tahmin edilebilirlik } \\
\text { Kolay anlaşılırlık } \\
\text { Açıklık }\end{array}$ & $\begin{array}{l}\text { Pekçok benzer öğe } \\
\text { Gizli köken yönleri } \\
\text { Doğrusal olmama } \\
\text { Birbirini etkileyen birlikte } \\
\text { çalışan parçalar }\end{array}$ & $\begin{array}{l}\text { Belirsiz, kaotik } \\
\text { Çatışan perspektiflere sahip } \\
\text { birçok paydaş } \\
\text { Gizli ve bilinmez pek çok öğe } \\
\text { Doğru/yanlış çözüm olmayışı } \\
\text { Ölçülebilir olmama } \\
\text { Benzerinin olmaması }\end{array}$ \\
\hline
\end{tabular}

\footnotetext{
${ }^{2}$ https://www.researchgate.net/publication/307545155_Citizen_Science_and_Environmental_Education_in_Italy_Po ssible_Developments_and_the_Role_of_Universities
} 
Bu gün gelinen noktada Irbite (2014, s. 412-413)'nin ifadesiyle de tasarım, karmaşık ve kötü huylu/belalı problemlerin (wicked problem) çözümü için benimsenen bütünleşik bir yaklaşım olarak tanımlanır hale gelmiştir. Tablo 1 tasarımcıların karşılaştığı problemleri, problem tipolojileri olarak ortaya koymaktadır. Kötü huylu problemler değerlendirmesinin ise, tasarımcıların ve tasarım teorisyenlerinin tasarım metodolojisi geliştirilmeye çalışıldığı yıllarda, matematikçi ve tasarımcı olup öğretmenlik yapan Horst Rittel tarafından, çizgisel, aşamalı tasarım süreci modeline eleştirel bir yaklaşım geliştirmek üzere ortaya çıkarıldığı görülmektedir. Rittel tasarımcıların üzerinde çalıştığı sorunların çoğunun kötü huylu problemler olduğunu ileri sürmüştür. Rittel (akt. Buchanan, 1992, s. 15)'e göre "kötü huylu problemler; enformasyonun ve tüm sistemdeki dallanıp budaklanmaların bütünüyle kafa karıştırıcı olduğu, birbiriyle çatışan değerleri olan pek çok müşteri ve karar vericinin bulunduğu, kötü şekilde formülleştirilmiş bir toplumsal sistem problem türünü oluşturmaktadır. Tasarımcıların her yeni durumda karşılaştıkları şeylere dair eğlenceli bir betimlemedir bu. Ama en önemlisi, pratiğin ardında yatan temel meseleye işaret etmesidir: tasarım düşüncesindeki belirlilik ile belirsizlik arasındaki ilişkiye.

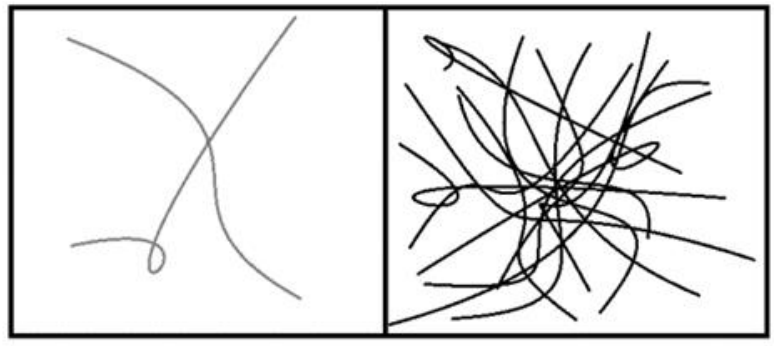

\section{Geleneksel Problemler Kötü Huylu Problemler}

Şekil 2. Kötü Huylu Problemler ${ }^{3}$

Rittel ve Webber (1973, s. 160) kötü huylu problemlere yönelik şöyle bir açıklamada bulunmuştur: "Tasarımcıların ilişkili olduğu problem türleri olan toplumsal problemler tabiatı gereği bilim adamlarının ve de bazı mühendislerin ilgili oldukları problemlerden farklıdır. Planlama problemleri doğası gereği kötü huyludur. Burada kötü huylu terimini "kötü huylu" (yumuşak huyluya karşıt), "kısır döngülü" (daire gibi) ya da "aldatıcı" (cüce cin) ya da "saldırgan"a (bir kuzunun uysallığının aksine bir aslan gibi) benzer anlamda kullanıyoruz". Kötü huylu problemlerin özellikleri ise tasarımın toplumsal gerçekliğine ilişkin betimlemeler olarak on madde ile şöyle ifade edilmektedir:

- Kötü huylu problemlerin belirli bir formülasyonu yoktur.

- Kötü huylu problemlerin durma kuralı yoktur.

${ }^{3}$ https://www.philosophersinamerica.com/2017/03/31/016-ep12-thats-a-wicked-problem-youve-got-there/ 
Özge KANDEMIR

- Kötü huylu problemlerin çözümleri doğru-yanlış olamaz, ancak iyi-kötü olabilir.

- Kötü huylu problemlerin çözümüne yönelik anında ve nihai hiçbir test yoktur.

- Her kötü huylu probleme yönelik her bir çözüm "tek adımlı bir işlem" dir; denemeyanılma yoluyla öğrenme fırsatı olmadığından, her girişim önemli ölçüde önemlidir.

- Kötü huylu problemler, sayılı (ya da kapsamlı bir şekilde tanımlanabilir) bir takım potansiyel çözümler ya da plana dâhil edilebilecek iyi tanımlanmış bir dizi izin verilebilir işlemler kümesi barındırmamaktadır.

- Her kötü huylu problem aslında eşsizdir.

- Her kötü huylu problem başka bir problemin belirtisi olarak düşünülebilir.

- Kötü huylu problemi temsil eden bir tutarsızlığın varlığı çeşitli şekillerde açıklanabilir. Açıklama seçimi sorunun çözümünün niteliğini belirler.

- Tasarımcının yanlış olma hakkı yoktur (Rittel vd. 1973, s. 161-167).

Bu çerçevede Buchanan tasarım sorunlarının "belirsiz" (tasarım sorunlarının hiç bir katı koşulu veya sınırı olmaması) ve "kötü huylu" olduğunu, çünkü tasarımın tasavvur ettiğinden ayrı özel bir konu alanı olmadığını dile getirmektedir. Tasarımın konu alanı kapsamı bakımından potansiyel olarak evrenseldir, zira tasarım düşüncesi insan deneyiminin her alanına uygulana bilmektedir. Fakat uygulama sürecinde tasarımcının özgül koşullarındaki sorunlar ve meselelerin içinde "tikel" bir konu keşfetmesi veya icat etmesi gerekmektedir. Bu da ister istemez mevcut konu alanlarına ilişkin ilkeleri, yasaları, kuralları veya yapıları anlamayı dert edinen bilim disiplinleriyle keskin bir tezat demektir. Tasarım esas itibariyle tikeli dert edinir ve tikelin bilimi yoktur (Buchanan, 1992, s. 16-17). Bu noktada Niederhelman (2001, s.87)'nın deyimiyle tasarımın ne olduğu ve ona nasıl katkı verebileceğinin ifade edilmesine duyulan ihtiyaç her zamankinden daha kritik hale gelmiştir. Tasarım disiplinin daha katı bir tanımı olmaksızın tasarımı; araştırmayı, işbirliğini ve dünyayı öğrenmeyi içeren daha büyük bir resmin içinde konumlandırmak daha zorlayıcı bir eylemi gerektirmektedir.

Gelinen bu noktada Buchanan'nın ifadesiyle günümüzde bütün erkekler ve kadınlar; işaretler, şeyler, eylemler ve düşünceler üzerine kurulu çerçevenin karmaşıklığı içinde iyi yaşamak için liberal bir tasarım sanatına intiyaç duymaktadırlar. Bir yandan, böyle bir sanat, bireylerin bu çerçeveye daha doğrudan katılmalarını ve gelişimine katkıda bulunmalarını sağlayacakken, öte yandan, profesyonel tasarımcıların araştırmalarında ustalar olarak görülebilmelerine olanak tanıyacaktır. Tasarımcıların işaretler, şeyler, eylemler ve düşünceler arasında yeni ilişkiler keşfetme yeteneği, tasarımın yalnızca teknik bir uzmanlık değil, yeni bir liberal sanat olduğunun da göstergesidir (Buchanan, 1992 , s. 14). Bu durumun ise günümüzde karmaşık problemlerin tanımlanması, bu amaçla verilerinin analiz edilmesi ve çözülmesi için tasarım araçlarına ve metotlarına ihtiyaç duyulamayacağını, 
buna karşın tasarımda farklı verileri ve bakış açılarını barındıran, çoklu ilişkilere olanak tanıyan bütünleşik bir yaklaşım biçiminin benimsenmesi gerekliliğini ortaya çıkardığı görülmektedir.

\section{Mekân ve Tasarımının Karmaşık-lığı}

Herbert Simon, 1962'de yayınlanan "Karmaşıklık Mimarisi” adlı ufuk açan makalesinde, bir yapının (structure) ne kadar basit ya da karmaşık olduğunun onu "eleştirel bir biçimde tanımlama biçimimize" bağlı olduğunu belirtmiştir (Simon, 1962, s.481). Bu noktada Lefebvre'nin deyimiyle; tarihsel, fiziksel, fizyolojik, dilsel, vb. içerikli çeşitli düşünceler, mekânın karmaşıklı̆ını daha önce göstermiştir (Lefebvre, 2014, s. 299). György Kepes 1965 'de, karmaşıklığı; sanat, mimari, bilim ve teknolojiyi birbirine bağlayacak bütünleşik yapısal bir düzen olarak tanımlamış (akt. Kolarevic, 2016, s. 27), fakat Venturi'nin deyimiyle karmaşıklık ve çelişki kavramları mimarlık dışında her yerde, Gödeli'nin matematikteki temel uyuşmazlık kanıtından, T.S. Eliot'un "zor" şiir çözümlemelerine ve Joseph Alberts'in "resmin usa aykırı niteliği" tanımına değin benimsenmiştir (Venturi, 1991, s. 17). Oysaki Lefebvre'nin ifadesiyle mekânsal eser (anıt, mimari eser) örneği, düzyazı metnin ya da bir şiirinkinden başka bir karmaşıklığa erişmektedir. Burada metin değil, doku söz konusudur. Bir dokunun, ağları ve örgüleri kapsayan, genellikle oldukça geniş bir mekândan oluştuğu bilinmektedir (Lefebvre, 2014, s. 234). Genel olarak da doğal mekân ile kentsel mekân aşırı yüklüdür. Burada her şey müsveddedir ve karmakarışıktır (Lefebvre, 2014, s. 162). Mekân kavramı zihinsel olanla kültürel olanı, toplumsalla tarihseli birbirine bağlayıp, karmaşık bir süreç oluşturmaktadır: (yeni, meçhul mekânların kıtaların ya da evrenin) keşfi; (her topluma özgü mekânsal örgütlenmenin) üretimi; (yapıtların: manzaranın, anıtsallığı ve dekoruyla birlikte şehrin) yaratılması (Lefebvre, 2014, s. 25). Bu çerçevede mekânın yorumlanması da Aydınlı (2004, s. 43)'nın ifadesiyle; kültürel, toplumsal, politik ve bağlamsal bütün pratikleri, yaşanan gerçekleri ve bilgiyi birbirleriyle ilişkili kılarak bir araya getirmektedir. Mekân, günümüzde felsefeden sosyolojiye ve tarihe, coğrafyadan modern fizik, biyolojiye uzanan geniş bir skala içinde çok kanallı, derinlikli ve dinamik bir kavram olarak tartışılmaktadır... Mekân artık, herhangi bir disipline ait sarsılmaz dogmalara ve ayrıcalıklı metodolojik kalıplara sığdırılamayan disiplinler ötesi bir kavram olarak ele alınmalıdır.

Bu çerçevede mekân ve tasarımına yönelik tek bir karmaşıklık tanımının bulunmadığı dikkat çekmektedir. Kolarevic, mimarlık bağlamında karmaşıklığın toplumsal, kültürel, programatik, işlevsel, biçimsel, mekânsal, tektonik, performatif, fenomenolojik olarak konuşulduğunu dile getirmektedir. Kolarevic'ın söylemiyle karmaşıklığı mimarlığa yeniden tanıtan Robert Venturi olmuş; Venturi, ilgilendiği karmaşıklık türlerinden hiç bahsetmemiş, hem mimarideki tarihsel karmaşıklıklara hem de tasarımın kendisiyle ilişkili karmaşıklıklara gönderme yapmıştır (Kolarevic, 2016, s. 27). Venturi, çeşitlilik ve belirsizlik yanında mimarlığa geçerlilik kazandıran temel özelliklerinden biri olarak gördüğü karmaşıklığa yönelik bakış açısını şu sözlerle dile getirmiştir: Sanıyorum bunlar, düzeni bozmamız için iki haklı gerekçedir: içerde ve dışarda, programda ve çevrede ve aslında yaşamın her düzeyinde var olan çeşitlilik ve karmaşıklığın kabul edilmesi ve insanın yarattı̆̆ı tüm düzenlerin özleri gereği sınırlı olduğunun bilinmesi. Koşullar ve durumlar düzene karşı koyduğu zaman düzenin boyun eğmesi veya bozulması gerekmektedir: unutulmamalıdır ki kural dışı durumlar ve belirsizlikler mimarlığa geçerlilik kazandırmaktadır (Venturi, 1991, s. 61). 
Özge KANDEMIR

Karmaşık ve çelişkili mimarlığın modern yaşantının ve sanatsal uygulamaların özünde var olan zenginliği ve anlam belirsizliğini kendine temel aldığını belirten Venturi (1991, s. 17), anlam açıklğından çok anlam zenginliğinden yana olduğunu dile getirmiştir. Bu belirtik (explicit) işlevler için olduğu kadar örtük (imlicit) işlevler için de geçerlidir. "Birinden birini" değil "her ikisini birden", beyaz veya siyahı değil, beyaz ve siyahı birlikte, bazen griyi yeğleyen Venturi, eğer mimarlık birçok düzeyde değişik anlamlar yaratabiliyor ve birçok yoruma yol açabiliyorsa, mekânı ve öğeleri aynı anda çeşitli biçimlerde okunuyor ve kullanılabiliyorsa, onun geçerli bir mimarlık olduğunu savunmuştur. Bu çerçevede mekân tasarımının sahip olduğu karmaşık yapıyı ortaya koymaya çalışan Venturi, işlev (fonksiyon) sorunlarının giderek artan karmaşıklı̆ına dikkat çekmiştir. Venturi'nin sözleriyle kendisinin kuşkusuz olarak burada sözünü ettiği şey, çağımıza özgü etkinliklerin niteliğinden ötürü karmaşık olan araştırma laboratuvarlarına, hastanelere ve özellikle kent veya bölge ölçeğindeki planlamalara ilişkin dev projelerin programlarıdır. Fakat boyutları sınırlı bir konut bile, eğer çağdaş yaşamın belirsizliklerinin anlatılması söz konusu olursa, son derece karmaşıktır. Bir programın araçlarıyla amaçları arasındaki bu karşıtık ise anlamlıdır (Venturi, 1991, s. 21). Lefebvre (1991, s. 226) de benzer bir yaklaşımla bir anıtın, hatta bir yapının veya basit bir kabinin girişinin algılanmasının bile, dilsel bir eylemden, söylemden, önermeden veya bir dizi cümlenden daha az karmaşık olmayan eylemler zinciri oluşturduğunu dile getirmektedir.

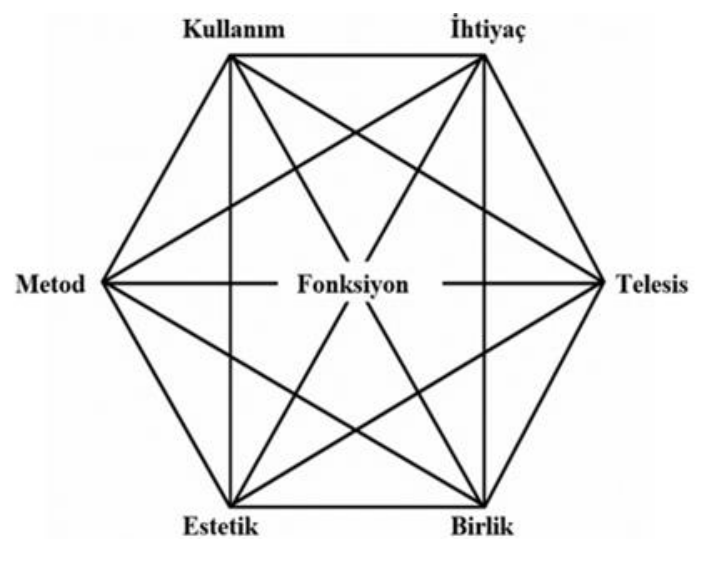

Şekil 3. Fonksiyonun Karmaşıklığı (Papanek, 1973, s. 26)

Bu noktada Papanek (1973, s. 27-39), tasarım eylemi için işlevin karmaşık bir yapıya sahip olduğunu dile getirerek, mekân tasarımı için de geçerli görülen işlev karmaşıklığına neden oluşturan dinamik eylemleri ve ilişkileri Şekil 3'de bir diyagram üzerinde göstermiştir. Burada fonksiyonu karmaşık hale getiren bileşenlerin altı madde halinde: metot, kullanım, ihtiyaç, telesis, estetik ve birlik olarak tanımlandıkları görülmektedir. Metot: araçların, süreçlerin ve malzemelerin etkileşim biçimine; kullanım: temelde çalışıp çalışmadığına; ihtiyaç: inşa ya da manipüle edilmiş isteklerden 
çok insanın ekonomik, psikolojik, ruhsal, teknolojik ve entelektüel ihtiyaçlarına; telesis: belirli hedeflere ulaşmada doğa ve toplum süreçlerinin bilinçli ve amaçlı kullanımına karşılık gelmektedir. Tasarımın telesetik içeriğinin, ona yol açan zaman ve koşulları yansıtması ve faaliyet göstereceği genel insan profilinin sosyo-ekonomik düzenine uyması beklenmektedir. ilişkilenme: insanın çoğunlukla çocukluk anılarına dayanan psikolojik durumuna dayanmakta; estetik: tasarımcının dağarcığındaki bizi harekete geçirip haz veren, güzel, heyecan verici, zevk ve anlam yüklü en önemli araçlardan biri olarak görülmektedir.

Moholy-Nagy, tasarım sürecinin ve projesinin karmaşıklı̆ı diye adlandıracağımız şeyin farkında görünerek; "çağımızın anahtarının, her şeyin ilişkili olduğunu görmek (görebilmek) olduğunu belirtmiştir". Nesnenin görünür bir varlığı bulunurken, ilişkiler özünde görünmezdir (Findeli, 2001, s. 10-11). Mekânın bir içeriği vardır. Mekân hakkında, toplumsal ilişkileri içerdiği, kapsadığı ve gizlediği söylenmelidir. Mekân bir şey olmasa da, şeyler (nesneler ve ürünler) arasındaki ilişkiler kümesidir (Lefebvre, 2014, s. 108). Bu noktada mantık Lefebvre'nin de dile getirdiği gibi ancak nesneyi oluşturan ilişkiler ağını belirtmektedir. Mantık ilişkileri ise genelde, "içerme-dışlama", "bağlaç-ayıraç", içerim-açıklama”, "yineleme-tekrarlama”, "geri dönüş-tekrar” gibi ilişkilerdir. Önermeler, yargılar, kavramlar, kavram zincirleri ya birbirlerini içerir ve bu içerimin sonucudurlar, ya da karşılıklı olarak birbirlerini dışlarlar. Bu mantık ilişkileri ne bir "gerçeklik" varsayar, ne de onun önüne konmuş bir "hakikat". Bu ilişkiler geometrik figürlerle temsil edilebilir: Kavramları simgeleyen ve en büyüklerin en küçükleri kapsadığı daireler. Bu temsil, kesinlikle formel oldukları için vazgeçilebilir olan ilişkileri açıklamaktadır. Mantık ilişkileri, matematiksel ilişkilerin, şekil, küme ve grup ilişkilerinin nedenini içerir (Lefebvre, 2014, s. 300). Mekânın mantığı var mıdır? Hem evet hem hayır. Belli ölçülerde matematiğin tümü bir mekân mantığı oluşturmaktadır. Bununla birlikte, "saf anlamda" tasarlanmış mekânın - Leibniz'in ortaya koyduğu gibi- ne unsurları vardır ne formu. Bu mekânın parçaları ayırt edilemediğinden "saf" özdeşliğe yakındır ki bu boştur, çünkü "saf anlamda" formeldir (Lefebvre, 2014, s. 303).

Bu noktada Harvey (1997, s. 93-94)'e göre "süreçler işin özündedir", bu yüzden üzerinde odaklaşmamız gereken nokta toplumsal etkileşim süreçleridir. Somut hayatta, "sağlıkı" kentsel çevrelerde bu süreçlere baktı̆̆ımızda, gördüğümüz, düzensiz olmaktan ziyade örgütlenmiş bir karmaşıklıktan oluşan girdisi çıktısı bol bir sistemdir, çeşitliliğe, karmaşıklı̆a ve beklenmedik şeyleri denetimli ama yaratıc biçimde ele alma kapasitesine yaşamsal biçimde dayanan bir toplumsal etkileşim canlılığı ve enerjisidir. Jacobs'a göre insanlarda "doğal” olarak var olan çeşitliliğe eğilimi engelleyen ve arazi kullanımında boğucu bir birörneklilik yaratan bazı piyasa süreçleri işlemektedir. Ama bu sorun, karmaşa ve karmaşıklığı düzensiz, çirkin ve umutsuz ölçüde akıldışı gördükleri için onlardan korkarak kendilerini çeşitliliğin düşmanı ilan eden planlamacılar tarafından büyütülmektedir. Jacobs şöyle yakınmaktadır: "Ne tuhaftır ki, kent planlaması kent halkının bağlarında ortaya çıkan kendiliğinden çeşitlenme süreçlerine saygı göstermez, ama bu tür bir çeşitlenmeyi sağlamak için çaba da göstermez. Oysaki Lefebvre (2014, s. 238)'nin deyimiyle toplumsal mekânın karmaşıklı̆̆ı, farklııkları serbest bırakarak ve ortaya sererek analize kendini sunmaktadır; basit gözüken şey kendi karmaşalarını ortaya koymaktadır. Bunlar ne geometrik olarak nesnelleştirilmiş (kare, dik- 
Özge KANDEMIR

dörtgen, daire, eğri, burgu), mekânın içinde, ne de zihinsel mekânın (mantıksal ayrılmazlık ve tutarIılıklar, yüklemlerin adlarla bağı vb.) içinde yer alırlar. Özellikle algının, temsilin ve mekânsal pratiğin birbirlerini gerektiren, öneren, üst üste binen düzeyleri, tabaka ve tortuları söz konusudur.

Dolayısıyla mimarlık, karakter olarak soyut kavramlarla iç içe olan karmaşık ve çelişkili bir yapıya sahiptir. Mimarlık; bina, malzeme, strüktür gibi somut ögeleri; zaman, boşluk, ortam, karakter gibi soyut ögeleri; statik, mekanik, topografya gibi ölçülebilir olan faktörleri; insan, doğa, kullanım, 'olay' gibi tam olarak tahmin edilemez olan faktörleri bir arada bünyesinde taşımaktadır (Yürekli ve Yürekli, 2004, s. 54.) Bu noktada mimari tasarımın karmaşık organizasyonel ve işlevsel gereksinimleri karşılaması gerekmekte bu nedenle de olası cevapları üretmek ve onları değerlendirmek kadar mevcut ve gerekli koşulların analizinin tekrarlanan sorgulamarını barındırmaktadır. Bu yinelemeli süreçlerle elde edilen ek bilgi, belirli bağlamın daha fazla analiz edilmesini veya önceden tanımlanmış tasarım hedeflerinin düzenlenmesini gerektirebilmektedir (Lawson, 2006, Arıdağ, et.al. 2016: 74). Bu noktada Salingaros'un da deyimiyle, mimarlık da karmaşıklık üretken bir araç haline gelmektedir. Bütün geleneksel toplumlar, karmaşık mimari tasarım ve sanat diline geçiş yaparak bireysel bir mimari biçim dili geliştirmiştir. 20. yüzyılın başlarındaki uluslararasılaşma, tüm bu gelenekleri, tasarım karmaşıklı̆ında büyük bir düşüşle silmiştir. Karmaşıklığı mimari biçime, mekâna ve yüzeye nasıl yeniden dâhil ederiz? Sorgulamasını yapan Salingoros (2014, s. 18), organize karmaşıklı̆ın, rastgelelik olarak algılanan dağınık karmaşaya karşı bir yanıt ortaya çıkardığını belirtmektedir. Bu noktada bir mimarın karmaşıklığı anlaması, kasıtlı üretimi ve ortaya çıkan karmaşıklığı bir tasarım aracı olarak nasıl yöneteceğini bilmesi gerekmektedir.

\section{Mekân Tasarımı Eğitiminde Karmaşık-lık ve Teorisi}

Yücel ve Aydınlı́nın deyimiyle stabil olmayan, akışkan, tahmin edilemeyen parametreler ve faktörler tarafından etkilenen tüm aktiviteler dünyaya bakış açımızı değiştirmemizi öngörüyor. Bugün her meslek alanında eğitimin amacı, bilgiye ulaşma yollarını bilen, mevcut bilgi üzerinden eleştirel düşünebilen bireyler yetiştirmektir. Mimarlık eğitiminde model arayışları yerine mimarın eğitimi üzerinden derinlemesine bir sorgulama, mimarlık eğitiminin eleştirel duruş ile sorunsallaştırılmasını sağlar hale gelmiştir (Yücel vd. 2015, s. 18). Bu sorgulamanın mekân tasarımıyla ilişkili olan tüm alanlar için de temel olduğu görülmektedir. Bu çerçevede Papanek, genel olarak tasarımcılar için eğitimin (neredeyse tüm eğitim gibi), becerilerin öğrenilmesi ve bir felsefenin edinilmesi üzerine kurulu olduğunu dile getirmektedir (Papanek, 2004, s. 285). Ancak Irbite günümüzde problem tanımlama ve çözme konusunda daha geniş bir bakış açısı olan yeni bir tasarımcı gereksinimin olgunlaştığına dikkat çekmiştir (Irbite, 2014, s. 413). Fakat bu gereksinimin günümüzde genel olarak benimsenen tasarım eğitimi yaklaşımıyla karşılanabilmesinin mümkün olamayacağı görülmektedir. Buchanan'ın deyimiyle "Eğitimciler, tasarım eğitiminin; yeni durumlara daha karmaşı ve eleştirel tepki verebilen tarih, teori ve eleştiri boyutlarından yoksun olduğunu fark etmişlerdir " (akt. Williams vd. 2015, s. 17). Bu noktada bir eğitimci olarak 21. YY için tasarım eğitiminin yapısını teorik, metodolojik ve etik açıdan sorgulayan Findeli (2001, s. 5), mevcut paradigmamızın pek çok şekilde karakterize edilebilir ve gerçekten de karakterize edilmiş olabileceğini dile getirirken, ona 
göre bu paradigmanın ana özelliklerini: metafizikle temellenen materyalist yaklaşım; pozitivist sorgulama yöntemleri ve onun agnostikçi (bilinemezci) düalist dünya görüşü oluşturmaktadır.

Pozitivizmin ise genel olarak, doğrudan gözleme indirgenemez gibi görünen bilimsel düşüncelerden kaçınan, koşullu açıklamaların bilimin bir işlevi olduğunu kabul etme konusunda tereddüt eden, dolayısıyla basitçe "kaydetme", "sınıflama" ve genel olarak da "betimlemenin" değeri üzerinde ısrar eden bir yapıya sahip olduğu dile getirilmektedir (Randall vd. 1982, s. 75-76). Bu nedenle de Wang'ın deyimiyle pozitivist paradigma irrasyonel yaratıcılığı yeterince açıklayamamaktadır. Pozitivizm, tasarım eğitimi için bir paradigma olarak kabul edildiği sürece de tasarımın; öznel, irrasyonel ve sonuç olarak da esrarengiz ve betimlenemez doğası asla tanımlanamaz ve açıklanamaz olacaktır (Wang, 2010, s. 179-180). Örneğin Venturi'nin de belirttiği gibi mimarlıkta kesin kurallar yoktur ama bir yapıya ya da kente her şey de uygulanamamaktadır. Mimar karar vermelidir; bu sırada yapacağı hassas değerlendirmeler onun temel işlevleri arasındadır. Neyin kaçınılmaz oluğunu, neyle uzlaşma olanağının olduğunu, neyin nerede ve nasıl anlatılacağını saptaması gereken kişi mimardır (Venturi, 1991, s. 61). Dolayısıyla tasarım temelde öznel yaratıclık üzerine odaklanırken, pozitivist üniversite paradigmasının nesnel rasyonaliteye odaklanması temel eleştiri konusu haline gelmiştir (Wang, 2010, s. 173). Tasarım yaratıcılığının nasıl öğretileceği yeni yaklaşımların gelişebileceği bir ortamın kurulmasını geniş ölçüde içermek zorundadır. Bu bağlamda okulun ve eğitimin fonksiyonu ne olmalıdır? (Papanek, 1973, s. 177).

Tasarım tarihçisi Victor Margolin (1998, s. 83), tasarımın başlangıından bu yana, seri üretim için ürünlere biçim verme sanatı olarak algılandığından, tüketici kültürüne sıkıca yerleştirildiğini belirtmiştir. Fakat Margolin (1998, s. 86-87), tasarımın günümüzde nesnelere biçim vermeye yönelik egemen paradigmadan ayrıştırıldıktan sonra, tasarımcıların projeye ne gibi katkıda bulunduğunu açıkça ortaya konulması gerektiğine dikkat çekmiştir. Margolin'e göre tasarımın gücü konsept ve planlamaya dayanmakta olup, önce bir fikir üretilir ve ardından bu fikir bir cisim, sistem veya çevre olarak, bir üründe somutlaştırıır. Tasarım, tarihsel olarak metalara şekillendirme sanatı olarak tanındığı oranda, tasarımcılar mühendislik, doğa bilimleri ve sosyal bilimler alanındaki diğer profesyonellerle çalışmayı sağlayacak bilgi türlerine ilgisiz kalmışlardır. Sonuç olarak, çoğu tasarım öğrencisi, tasarımın müdahil olabileceği sınırlı bir dizi duruma maruz kalır. Okulda başlayan ve tasarım dergilerinde ve profesyonel konferanslarda devam eden bu tür bir sosyalizasyon, dar bir "ürün tasarımı" imajını güçlendirmektedir.

Fuard-Luke (2002, s. 2)'un ifadesiyle var olan tasarım paradigmasının mirası, devlet ve milyarlarca tüketicinin onayladığı ticari çıkarlar ile olan gizli anlaşma, endişe vericidir. Tasarım topluluğu, yaratıcı içgüdülerini ekonomik modellerin sınırları içinde kaybederek, ekonominin ötesindeki dünyada var olan sorumluluklarını büyük oranda göz ardı etmiş̧ir... Tasarımcıların son 50 yılda 'tüketici' ekonomisinde oynadığı roller, tasarımcıların karşı karşıya olduğu büyük sorumlulukların hatırlatıcısı haline gelmiştir. Bu noktada Williams ve Rieger (2015, s. 17), çağdaş post-endüstri toplumunun sorunlarının gerçekte, bileşenler ve ürünler olmadığını, sorunun sistemler ve topluluklar düzeyinde görülmesi gerektiğine dikkat çekmiştir. Bu söylemde ima edilen şey: karmaşıklığın; insanlar, nesneler, ve düzenlemeler arasındaki etkileşim ağının içerisinde tanınmasıdır. Bu noktada Findeli (2001, 
Özge KANDEMIR

s. 17), eğer tasarımın "ürün geliştirme, pazarlama iletişimi ve teknolojik fetişizmin bir dalı" haline gelmesini veya kalmasını istemiyorsak, buna bir çözüm geliştirilmesi gerektiğini; bu süreçte reaktif bir tutumda olmak yerine proaktif olmak zorunda olunduğunu, bunun içinde "gelecek için yeni senaryolar" önerilmesi gerektiğine dikkat çekmiştir. Kwinter'ın ifadesiyle özünde tasarım, her örneğinde 'devrimsel' olmak zorundadır (Kwinter, 2013, s. 331). Findeli (2001, s. 13), yeni bir perspektif içinde tasarımın amacının (az ya da çok) yakın gelecekte ulaşılması gereken ideal bir hedef olarak algılanmaması gerektiğini belirtmiştir. Tasarımın amacı bir ufuk (horizon), değerler kümesine rehberlik ve referans alınması gereken değer bilimsel (axiological) bir peyzaj olarak değerlendirilmek zorundadır.

Bu doğrultuda Wang tasarım eğitimini bu yönde değiştirme olasılığının, disiplin için önerilen şu anki baskın pozitivist paradigmanın yerine geçen ve karmaşa teorisinin son zamanlardaki gelişimine dayanan yeni paradigma ile, paradigma değişimi doğrultusunda mümkün olabileceğini dile getirmiştir. Bu, tasarım teorisinin ve uygulamasının Alain Findeli (2001)'den ödünç bir ifadeyle pedagojik ve sosyokültürel olarak "karmaşıklaştırılması" anlamına gelecektir. Bu tür değişiklikler, tasarım epistemolojisini yeniden düşünmeyi, sistematik tasarım süreçlerinin daha fazla farkına varılmasını, projeleri ve etkinlikleri tasarlamak için çok disiplinli yaklaşımların benimsenmesini içermektedir (Wang, 2010, s. 174). Fuard-Luke'un deyimiyle böyle bir paradigma kayması, kişinin dünyadaki vizyonunun dönüşümünü ve kişinin varlığının tüm yönlerini içermektedir: akıl, hayal gücü, duyarlılık ve irade (Fuard-Luke, 2002, s. 2). Bu noktada David-Ng (2014, s. 7)'nin de dile getirdiği gibi "kendini organize etme becerisinin, içinde bulunulan karmaşık dünyada gelişmek için herhangi bir organizasyonun sahip olması gereken hayati bir özellik olduğunun fark edilmesi önemli hale gelmektedir. Bu noktada Findeli (2001, s. 15) tasarımın, yeni paradigmanın şartlarına göre ayakta kalması ve gelişmesi için, ürün merkezli tutum yerine yeni bir tutum benimsemesi gerektiğini vurgulayarak, bu tutumun sahip olması gerektiği özellikleri dört senaryo altında topladığını ifade etmektedir. Bu senaryolar temelde:

- Sistem yaklaşımına ve karmaşıklığa kayış, başka bir ifadeyle 'problem ve çözümünden' sistemin farklı durumlarına kayış, maddi artifaktların sistem içindeki aktörler lehine arka plana itilmesi. "Sanat eseri olarak ürün" paradigmasının bir diğer ifadeyle de artifakt fetişizminin sona ermesi.

- Tasarım özünün sistematik olarak sorgulanması (problemin karmaşıklaştırılması), tasarımcıların nesnenin "karanlık yüzü" nü aramaya yönlendirilmesi. Tasarımcıların tasarım ve mühendislikte kullanılan klasik "ürün tanımları" ndan ziyade insan bağlamıyla daha çok ilgilenir hale gelmesi.

- Yaşam biçimimize şekil veren ve düzenleyen hizmetlerin kendi başına bir ürün olduğu gerçeğinin sorgulanması. Maddi olmayan nesneler ve karmaşık sistemler olan hizmetlere, maddi ürünlerin tasarımı için geliştirilen metodolojilerin aktarılabilmesi. 
- Ekolojik gerekçelerle ürünün yok olmasının ön görülmesi ve temelde sürdürülebilir tasarım yaklaşımlarının benimsenmesidir.

Bu çerçevede Wang (2010, s. 178)'ın ifadesiyle Findeli, tasarım gibi tasarım eğitiminin de bir sistem teorisine intiyaç duyduğunu dile getirmiştir. Bu teori yalnızca planlanmış artifaktların değil, tasarımcının iç dünyaları ile kullanıcı (lar) arasındaki ve de dış dünyalar toplumu ile biyosfer arasındaki karşııklı görünmez ilişkilere izin verecek ve bu ilişkileri anlayacak bir sistem teorisinin geliştirmesi gerektiğini savunmaktadır. Böyle bir paradigmada, tasarım, bir soruna çözüm değil, değerlerin ve olanakların açık bir ufku haline gelecektir. Başka bir deyişle, hem tasarım metodolojisi hem de tasarım eğitimi, daha önce olduğundan farklı olarak daha karmaşık ve anti-rasyonel hale getirilecektir. Bu yeni paradigmaya yaygın olarak verilen ad ise "karmaşıklık teorisi"dir. Fakat Mitchell'in (2009) belirttiği gibi, ne tek bir karmaşıklık bilimi ne de tek bir karmaşıklık teorisi henüz mevcut değildir (akt. Kolarevic, 2016, s. 26). Karmaşıklık ve Eğitim üzerine yaptığı araştırmalarında Kuhn, karmaşıklık teriminin, bir düşünce tarzını veya bir paradigmatik yaklaşımı ifade ettiğini; başkalarının bunu Karmaşıkık Teorisi olarak adlandırdığını ve karmaşıklığın temelde şemsiye bir tanım oluşturduğunu belirtmektedir. Kuhn'a göre bu tanım kapsamında araştırmacılar, bilimsel kuramların, bazı olayların kaotik veya rastgele görünmesine rağmen aslında "daha büyük tutarlı bir işlemin parçası olduğu" görüşünü paylaşan bir dizi yeni bilimsel teoriyi gruplandırmaktadır (Kuhn, 2008, s. 178). Yapayın Bilimleri adlı çalışmasında Herbert Simon ise özde karmaşıklığın, görünür kaos içindeki gizli örüntüyü bulmaya yönelik olup, "basitlik için sadece bir maske" olduğunu belirtmiş̧ir (Simon, 1996, s. 1).

Karmaşıkık teorisi, basit neden-sonuç ilişkilerinin olmadığı karmaşık sistemlerle ilgilenirken (Beabout, 2010, s. 12), karmaşık sistemlerdeki ilişkilerin doğrusal olmayıp, yapılan tercihler ve etkileşimler nedeniyle evrenin öngörülemeyen hale getirdiğini ileri sürmektedir (Tetenbaum, 1998, s. 21). Bu bağlamda dünyanın dinamik, tutarsız, lineer olmama ve değişkenlik kavramlarıyla birlikte değerlendirildiği, onu oluşturan sistemlerin de, lineer olmayan ilişkilerin dinamik ve öngörülemez unsurlarıyla tanımlanır hale geldiği dikkat çekmektedir. Bu noktada Wang, karşmaşıklık teorisi için eğitimin, gerçeği bulma ve davranışı kontrol etmeye yönelik problem çözme eylemi olmadığını; buna karşın eğitimin, açık uçlu bir keşif süreci, yaratıcı bir biçimde ortaya çıkan potansiyellerle bütün olarak kendini düzenleyen bir sistem olarak algıladığını ortaya koymaktadır (Wang, 2010, s. 178-179). Wang, karmaşıklığın; pozitivizmin açıklamalara ve olması gerekenlere duyduğu saygı yanında temelde "ne" olduğuna yönelik vurguları paylaştığını dile getirmektedir. Bu durum, karmaşıklığın öznelliğe ve yaratıclığa değer vermesine rağmen tümüyle objektifliği ve rasyonelliği de göz ardı etmediği anlamına gelmektedir. Gerçekte bir paradigma olarak karmaşıklık, tasarım eğitiminin bu birbirine zıt iki öğesinin iddiaları arasında iyi bir entellektüel denge korumaktadır (Wang, 2010, s. 175). Cleanth Brooks, Donne'un sanatının “aynı anda iki farklı şey söylediğini ileri sürerek, günümüzde hiç kimsenin bunu yapabilecek yetenekte olmadığını "ya biri ya öteki" geleneğine göre eğitildiğimizi ve "hem o hem bu..." geleneğinin izin vereceği, daha ince ayrım ve düşüncelere olanak sağlayan anlayış çevikliğinden (anlayış olgunluğu yerine kullanılmıştır) yoksun olduğumuzu dile getirmiştir (akt. Venturi, 1991, s. 28). Oysaki yeni bilimler ortaya çıkarmaktadır ki, bizler ya/ya 
Özge KANDEMIR

da'ların olduğu bir dünyada değil "hem/hem de"'lerin geçerli olduğu bir dünyada yaşamaktayız. Bu noktada karmaşıklık ya/ya da'ların olduğu bir dünyada değil “hem/hem de"'lerin geçerli olduğu bir dünya tanımlamaktadır (Garmston vd. 1995, s. 6).

Bu noktada karmaşıklık teorisinin tasarımda hem o hem bu kavramının; hem verilerin çoklu olarak görülmesini hem de veriler arasındaki ilişkilerin çoklu ve çok yönlü olarak kavranıp değerlendirilmesini gerekli kıldığı açığa çıkmaktadır. Bu veriler ele alınan her bir problemde farklıık gösteren, her an değişip gelişebilen dinamik yapılar olarak algılanmalıdır. Kwinter, bu çerçevede gerçekliklerin zamanın içinde bir oluş olarak kavranması gerekliliğine dikkat çekmektedir. Zamanın böyle sorunsallaştıııması mekânın da öncelikli rolüne meydan okumakta ve 'varlık'ın karşısına 'oluş'u koyan klasik problemi yeniden üretmektedir (Kwinter, 2001, s. 11). Bu noktada tasarım ve mekân tasarımı eylemlerinin ön görülemez, doğrusal olmayan karmaşık bir yapıya sahip olduğunun farkına varılmasına; tasarım sürecinin hem/hem de yaklaşımıyla görünür olan yanında ansızın açığa çıkan çoklu verilerle ve ilişkilerle "bütünleşik" olarak ele alınmasına duyulan ihtiyacın karşılanmasında karmaşıklık teorisinin tasarımcılar için bir sorgulama ortamı ve aracı oluşturduğu görülmüştür.

Bu noktada Capra (1996)' ya göre, 20. yüzyılın biliminde çeşitli disiplinlerde gelişen sistem düşüncesi, indirgenemeyen bütün kavramını ortaya koymuştur. Yaşamın doğasının anlaşılabilmesi için yapılan araştırmaların temel düşüncelerinden olan bütünsel bakış, mimarlık kavramlarında da yansımasını bulmuştur. (Yücel vd. 2015, s. 18-21). Venturi'nin ifadesiyle de karmaşıklığa ve uzlaşmaya dayanan bir mimarlık zaten "bütün"den vazgeçmemektedir. Bu dışlamaya başvurarak elde edilen kolay bir bütünlük değil, içerme yoluyla erişilen zor bir bütünlüktür (Venturi, 1991, s. 142). İçeren bütün, karşıtıklara dayanan mimarlığın özünde vardır (Venturi, 1991, s. 172). Genel olarak bütünlük (integrity) ise, bölünmemiş ya da parçalanmamış duruma, materyal bütünlüğüne, tamlığa ya da tümlüğe işaret etmektedir (Jokilehto, 2002, s. 298). "Bütünlemek" (bir araya getirmek ya da bir bütüne doğru parçaları birleştirmek) ve "bütünleşik" (uyumlu bir bütün sağlamak üzere ayrı öğeleri birleştirmek ya da koordine etmek) kelimesi "bütün yapmak, yenilemek, tazelemek" anlamına gelen Latin integrare'den gelmektedir (Benzel, 1997, s. 18). Papanek (1973, s. 284-286)'in ifadesiyle özünde insan eylemleri de (nefes alma, dengeleme, yürüme, algılama, tüketme, sembol oluşturma, toplumu üretmesi) tümüyle birbiriyle ilişkili ve birbirine bağlıdır. Bu noktada bütünleşik tasarım da bu bütünlük (unity) konusunda endişe duyulmasına olanak sağlayacaktır.

Turan ve Bayatın'ın ifadesiyle de, bütün; insanın evrenle ilişkisi söz konusu olduğunda açığa çıkan ilk kavramdır. Bu ilk kavram her bir insanın olanaklı evrenin tamamına yaygın halde oluşunu vurgulamakta; sayısız evrensel özellik ancak insan biriminde açığa çıkmaktadır. Bütün hem insana hem de evrene "yaşamsal" bir ilişkiyle işaret ederek iki varlığı birbirinden ayrı düşünmenin olanaksızlığını ortaya koymaktadır. Nerede bir anlamlandırma, düşünme, yorumlama, sorgulama, algılama, bilme, duyma, hissetme, açığa çıkarma ve yapma varsa orada yaşamdan ve bir bütünden söz etmek mümkündür. Uzmanlık olarak tasarım bağlamında nerede bir "proje" varsa ve gündelik tasarlama bağlamında nerede bir "kullanım" varsa orada aralanmakta olan böyle bir bütün vardır. 
Bu bütüne "yaşam bütünü", "anlam bütünü", "biliş bütünü" gibi çeşitli tamlamalarla işaret edilebilir. Bununla birlikte tasarım kuramı bağlamında en uygun ifade "yapım bütünü" olabilir (Turan vd. 2010, s. 6-7). Bu noktada Papanek, eğer bütünleşik tasarım, bütün olarak tasarlama konusunda konuşulacaksa tasarım sürecine kapsamlı bir biçimde yaklaşan tasarımcılara ihtiyaç duyulduğunu belirtmiştir. Papanek'in deyimiyle fakat acı bir biçimde, çok donanımlı öğrenciler henüz herhangi bir okul tarafından ortaya çıkartıımamıştır. Onların eğitimi için eğitim, daha az uzmanlaşmış olacak ve tasarımla uzaktan ilişkili olduğu düşünülen birçok yeni disiplini kendisine alacaktır (Papanek, 2004, s. 295). Bu noktada, tasarımın daha karmaşık sosyal ve kültürel bir bağlamla ilişkili olarak daha kapsamlı ve eleştirel incelenmeye intiyaç duyduğunu aktaran Williams ve Rieger (2015, s. 17), Buchanan'nın bu duruma ilişkin ortaya koyduğu ek anlayışı şu sözlerle dile getirmiştir: Eğitimciler, tasarım eğitiminin, yeni durumlara daha karmaşık ve eleştirel tepki verebilen tarih, teori ve eleştiri boyutlarından yoksun olduğunu fark etmiştir. Buchanan, işbirliğini ve çapraz disiplinliği, günümüz tasarımcılarının karşılaştığı kötü huylu problemlerle uğraşmak için gerekli olan "ayırt edici düşünce biçimi” ni besleyen anahtar yetenekler olarak tanımlamaktadır.

Bugün bilginin sürekli değiştiği bir ortamda, mimarın (mekân tasarımı üzerine uzmanlaşan tüm bireyler için geçerli olduğu düşünülmektedir) öncelikle bu değişime ve farklılığa cevap verebilecek düşünme yollarını bilmesi gerekli hale gelmiştir. Aydınlı (2001)'nın ifadesiyle bilgiye ulaşabilme ve ona her bağlamda farklı bir konum kazandırabilme bilinci, onu dönüştürebilme yetisi, kalıplaşmış, kural haline gelmiş bilginin aktarılmasının önüne geçmelidir. Mimarlığın kesin olmayan belirsizlik ve çelişki içeren tüm konularında ki bu durum günümüzde giderek etkin olmakta; esnek düşünebilen, sorgulayan, bilgiyi 'yeni' olana dönüştürebilen, karmaşıklık ve çeliş̧i içeren sorunlara karşı toleransIı olabilen bir mimar yetiştirmek, eğitimde öncelik kazanmalıdır (Yücel vd. 2015, s. 20). Bu noktada Deleuze, hayatı bir bütün olarak düşünme gücüne en iyi karşılık gelen kavramın farklılık olduğunu belirtmiştir. Hayat farklııktır; farklı düşünme, farklı olma ve farklılıklar yaratma gücüdür (Colebrook, 1998, s. 24). Deleuze'a göre de başııca üç ana düşünme tarzı olan; sanat, bilim ve felsefe hayatı dönüştüren güçlerdir. Sanat duyu-verileri ve duyguların, bilim işlevlerin, felsefe ise bir düşünme yönelimi veya yönü üreten kavramların yaratılmasına yöneliktir (Colebrook, 1998, s. 22-35). Bu noktada tasarım ve eğitiminin çapraz disiplinli bir tasarım yaklaşımla ele alınması gerekliliği giderek artmaktadır. Bekdaş'ın da ifadesiyle dünyada birçok alanda olduğu gibi, tasarım alanında da disiplinler arası çalışmalar yapıımaktadır. Disiplinler arasında ilişki kurma çabası ile hareketlilik sağlanarak bilgi üretimi olmaktadır. Bu bilgi hem günümüz ortamı gibi devingen, hem de sınırların ortadan kalktığı bütüncül bir bilgidir; tek bir noktaya odaklı değil, karmaşık ve birbirine bağlı bir sistematiktir (Bekdaş, 2018, s. 325). Papanek'e göre daha stabil bir tasarım düşüncesi ürünü (ya da aracı, ya da ulaşım cihazlarını, ya da yapıyı ya da şehri) insan ve çevresi arasındaki lineer bağ olarak görmektedir. Gerçekte ise insanı, araçlarını, ortamını, düşünme biçimini, planlama şekli, kendini ve çevresini manipüle etmesini doğrusal olmayan, simultane, bütünleşik, kapsamlı bir bütün olarak görmek zorundayız. Bu yaklaşım bütünleşik tasarımdır (Papanek, 1973, s. 284).

Bütünleşik tasarım ise Papanek'in deyimiyle de lineer bir dizilim yerine eşzamanlı olarak meydana gelen bir dizi biyolojik işlevler, bir takım beceriler, teknik veya mekanik süreçler dizisinden 
Özge KANDEMIR

oluşmaktadır. Bu eşzamanlı "olaylar"; ilk gübreleme, gelişimsel büyüme, üretim (veya mimesis) ve değerlendirme, daha sonra da yeniden başlatma ya da yenilenme ya da her ikisine yol açan, böylece kapalı bir geribildirim döngüsü oluşturan olaylar olarak düşünülebilir. Bütünleşik tasarım, özenli bir analizle, sorunun ait olduğu karmaşıklığın seviyesinde kurulmasını gerektirmektedir (Papanek, 2004, s. 294). Benzel (1997, s. 18) ise, mekân tasarımı için bütünleşik tasarım "integrated design" sözcük öbeğini, odanın, yapının, peyzajın ve şehrin ayrık varlıklarını koordine eden bir kavram olarak kullanmaktadır. Benzel'e göre, bütünleşik tasarım temelde, ortak zemini ve sınırları yeniden değerlendiren ve çeşitli ölçekleri, disiplinleri tek bir organize ağa yönelik olarak bir araya getiren bir felsefe oluşturmaktadır (Benzel, 1997, s. 18). Sonuç olarak bu gün gelinen noktada tasarımın, karmaşık ve kötü huylu/belalı problemlerin çözümü için benimsenen bütünleşik bir yaklaşım olarak benimsenir hale gelmesi gerekli görülmektedir. Burada Sayın’ın dan aktarımla ifade edilen "bütün"ün (burada özellikle üzerinde durulan sanatsal, mimari "bütün”) farklı bakış açılarının oluşturduğu bir çokluklar birliğinden, varolan duygu, heyecan, dil, düşünce vb. öznel ve nesnel bileşenlerden oluştuğunun (Sayın vd. 2009, s. 69) farkına varılması önemlidir.

\section{Sonuç}

Tasarım kavramının, tarihi süreçte etkinliklerini ve sonuçlarını belirleyen pek çok tanım, açıklama ve yaklaşım biçimi içerdiği görülmektedir. Fakat günümüzde tasarım araştırmaları (design research) kapsamında yapılan sorgulamalarda tasarımın ürün açığa çıkarmaya yönelik bir eylem olmasından öte, bir düşünce üretim ortamı ve aracı olarak algılanır hale geldiği dikkat çekmektedir. Tasarım problemlerinin duruma özel, genellenemez, ön görülemez ve indirgenemez yapısının kabulü, tasarımcının çok yönlü düşünmesini, problemlere kendi karmaşıklık seviyesi içinde yaklaşmasını gerektirir hale gelmiştir. Burada karmaşık-ık; bileşenlerin sabit sayılara, sabit ilişkilere, sabit davranışlara sahip olmadığı bir oluşuma karşılık gelirken tasarlama eyleminin bir düşün eylemi olduğunu tasarımcıya yeni-yeniden hatırlatan bir kavram haline gelmektedir. Genel olarak tasarımda özelde ise mekân tasarımında var olan bu çok yönlü karmaşıklığın, objeden-mekâna görünür dünyanın altında yatan örtük verilerin varlığının kabulüne olanak tanırken, özgün ilişkilerin keşfini de olanaklı kıldığı görülmektedir. Bu keşif sürecine ışık tutacak yaklaşımın ise Karmaşık Teorisinin temel sorgulamalarından beslenmesi gerektiği düşünülmektedir. Karmaşıklık teorisi, tasarlama eylemi için ele alınan problemlere ilişkin görünür kaos içindeki gizli örüntüyü bulmaya yönelik bir araç olarak değerlendirilmektedir. Bu araç aynı zamanda mekân tasarımı eğitimi için gerekli olan çağdaş yaklaşım biçiminin yakalanmasında da bir sorgulama ortamı olarak görülüp değerlendirmektedir. Bu yaklaşım biçimi aynı zamanda Mekân Tasarımı Eğitimini de çağdaş kılacak bütünleşik bir yapıya sahiptir. Bu çerçevede karmaşık-lık ve teorisinin tasarım eyleminde indirgeyici, seçime dayalı ya-ya daların yerine; içermeye dayalı hem-hem de lerin benimsendiği "bütünleşik yaklaşıma/tasarıma", mekân tasarımı eğitim ortamlarını yönlendiren sorgulamalarıyla eğitimciler tarafından keşfedilmeyi gerektiren veriler içermektedir. Bu edimle ele alınan çalışmada karmaşık-lık kavramı ve teorisi; tasarım ve mekân tasarımının doğasının yeni-yeniden farkına varııması ve bu yönde 
eğitim çevrelerine yönelik çağdaş bir yaklaşım geliştirilmesine ilişkin olarak incelenip değerlendirilmiştir. Bu doğrultuda elde edilen veriler mekân tasarımı ve eğitiminde:

- Bütünsel bakışın oluşturulması ve geliştirilmesinin, bu doğrultuda öznel ve nesnel, somut ve soyut bileşenlerin oluştuğu bütünün farkına varılmasının,

- Dışlama değil, içerme yoluyla erişilen bütünlük kavramının benimsenmesinin, bu doğrultuda çoklu verilerin bütünleşik olarak ele alınmasının, "bütünleşik tasarım" yaklaşımının benimsenmesinin,

- Somut bileşenler yanında görünmez veri ve ilişkiler ağının varlığının keşfedilmesinin, bu doğrultuda değişken, duruma ve bağlama özel yeni ilişkilere olanak verilmesinin,

- Eleştirel düşüncenin ve eleştirel bilginin geliştirilmesinin, bu doğrultuda bilgiye ulaşabilme ve onu dönüştürebilme yetisinin desteklenmesinin, kendi kendini organize etme becerisinin geliştirilmesinin,

- Nesnel rasyonalite ile öznel yaratıcılığın birlikte var olmasına olanak tanınmasının, bu doğrultuda akıl, hayal gücü, duyarlılık ve iradeye dayalı tasarımcı vizyonunun geliştirilmesinin,

- Farklı bilim dalları ve alanlarının ortaya koyduğu bilgi türlerinin değerlendirilmesinin bu doğrultuda çok disiplinli yaklaşımların benimsenip, yeni disiplinlerin sürece dâhil edilmesinin,

- Çapraz disiplinli bakış açısının geliştirilmesinin, devingen, sınırların ortadan kalktığı bütüncül bilgiye dayalı farkındalığın elde edilmesinin önemli hale geldiği görülmüştür.

\section{Kaynaklar}

Arıdağ L. Koş, F. C. (2016). Current Approaches in Structural Design In Case Of Architectural Education. International Refereed Journal of Design and Architecture.7 (7): 73-84.

Aydınlı, S., (2004). Mimarlık ve felsefe. İçinde Şentürer, Ş. Ünal, A.Atasoy (Ed.), Epistemolojik Açıdan Mekân Yorumu, İstanbul, Türkiye: Yem Yayınları, ss. 40-48

Bayazıt, N., (2004). Endüstriyel Tasarımcılar İçin Tasarlama Kuramları ve Metotları, İstanbul, Türkite: Birsen Yayınevi.

Beabout, B.R., (2010). Urban School Reform and the Strange Attractor of Low-Risk Relationships. School Community Journal, 20(1):9-30

Bekdaş, H. D., Yıldız, S. (2018). Tasarım ve Sanat Arakesitinde Kavramsal Düşünme: Enformel Eğitim Çalışmaları (2009-2015) MEGARON, 13(2):324-333.

Benzel, C., (1998). The Room in Context: Design Beyond Boundaries. New York, USA: Mcgraw-Hill.

Buchanan, R., (1992). Wicked Problems in Design Thinking. Design Issues, 8(2):5-21 
Özge KANDEMIR

Colebrook, C., (1998). Gilles Deleuze. Çev: Cem Soydemir. Ankara, Türkiye: Bagimsis Kitaplar.

Crawford, R. (2016). What can complexity theory tell us about urban planning? New Zealand Productivity Commission. Research Note 2016/2 ISBN: 978-0-478-44032-4

Crilly, N. (2010). The structure of design revolutions: Kuhnian paradigm shifts in creative problem solving. Design Issues: 26(1). 54-66.

David Ng, F. S.(2014). Complexity-based learning-An alternative learning design for the twentyfirst century. Cogent Education 1: 970325

Fındeli, A. (2001). Rethinking Design Education for the 21st Century: Theoretical, Methodological, and Ethical Discussion. Design Issues, 17(1)5-17

Garmston R., Wellman, B., (1995). Adaptive Schools: In a Quantum Universe. Educational Leadership, 52(7): 6-12

Harvey, D., (1997). Postmodernligin durumu. İstanbul, Türkiye: Metis Yayinlari.

Heskett, J. (2002). Toothpicks and Logos Design in Everyday Life. New York, USA: Oxford U. Press.

Irbite, A., (2014). The Importance Of The Paradigm Shift In The Development Of Design Industry And Design Education. Proceeding of the International Scientifical Conference May 23th 24th, 2014 Volume II.

Jokılehto, J. (2002). A history of architectural conservation. Oxford, USA: Butterworth-Heinemann Publishing.

Jonas, W., (1996). System Thinking in Industrial Design. Proceeding of System Dynamics, Cambridge, Massachusetts 22-26:241-244.

Kant, E., Newell, A., (1984). Problem Solving Techniques for the Design of Algorithms. Information Processing and Management. 20(1-2):97-118

Kıel, D., (1997). Embedding Chaotic Logic into Public Administration Thought: Requisites for the New Paradigm. Public Administartion and Management: An Interactive Journal. 2(4):26-39.

Kolarevic, B., (2016). Simplexity and Complicity in Architecture.Keynotes-Volume1-eCAADe 34|25.

Kuhn, L., (2008). Complexity and Educational Research: A Critical Reflection. Complexity Theory and The Philosophy of Education. Ed. Mark Mason. Wiley-Blackwell .pp. 169-180.

Kwınter, S., (2001). Architectures of time: toward a theory of the event in modernist culture. Cambridge, England: MIT Press. 
Kwınter, S. (2013). Neuroecology: Notes Toward a Synthesis. Ed. Warren Neidich. The Psychopathologies of Cognitive Capitalism: Part Two. Berlin, Germany: Archive Books, 313334.

Lefebvre H., (1991). The Production of Space. Translated by . Donald Nicholson-Smith. Cambridge, England: Blackwell Publishing.

Lefebvre, H., (2014). Mekanın Üretimi. Çev. Işık Ergüden. İstanbul, Türkiye: Sel Yayıncılık.

Luhmann, N., (1985). A Sociological Theory of Law, London, England: Routledge and Kegan Paul.

Margolın, V., (1998). Design for a Sustainable World. Design Issues, 14(2):83-92

Mitcham, C., (1995). Ethics into Design, Discovering Design, Explorations in Design Studies. Ed. Richard Buchanan, Victor Margolin., London, England: Thu University of Chicago Press. 73189.

Mikulecky, D.,C.,(2001). The emergence of complexity: science coming of age or science growing old? Computers \& Chemistry. 25(4):341-348.

Niederhelman, M. (2001). Education through design. Review of the Re-inventing design education in the university' conference, Design Issues, 17(3): 83-87.

Papanek, V., (1973). Design for the Real World, Human Ecology and Social Change, London, England: Bantam Books.

Papanek, V., (2004). Design for the Real World, Human Ecology and Social Change, New York, USA: Thames \& Hudson Ltd.

Randall, J. H., Buchler, J.,(1982). Felsefeye Griş. Çeviren: Ahmet Arslan. İzmir, Türkiye: Ege Üniversitesi Sosyal Bilimler Fakültesi Yayınları

Rittel, H., W., Webber, M., M, (1973). Dilemmas in a General Theory of Planing. Policiy Sciences. 4: 155-169.

Rodriguez L., Peralta, C., (2014). From Product to Service Design: A Thinking Paradigm Shift. FORMakademisk. 7(3):1-27

Ruelle, D., (2014). Raslantı ve Kaos. Çev: Deniz Yurtören. İstanbul, Türkiye: Say Yayınları.

Sala, N. (2004). Complexity in architecture:A small scale analysis. Design and Nature II, M. W. Collins \& C. A. Brebbia (Editors) WIT Press

Salingaros, N., A., (2014). Complexity in Architecture and Design. Oz Journal, 36:18-25.

Sayın, T., Gorbon, F. (2009). Mimari Tasarım/Söylem Bütünün Hermenötikselliği. Tasarım+Kuram, 7: 69-81 
Özge KANDEMIR

Schrag, C., O., (2006). Heidegger Felsefesinde Fenomonoloji Varlık Bilim ve Tarih. Çev. Serdar Şen. ÇTTAD. 13: 205-215.

Simon, H., (1962). The Architecture of Complexity. Proceedings of the American Philosophical Society, 106(6):467-482.

Simon, H., (1996). The Sciences of the Artificial - 3rd Edition, MIT Press

Tetenbaum, T., J., (1998). Shifting Paradigms: From Newton to Chaos. Organizational Dynamics, Spring:21-32

Turan, A .Z., Bayazıt, N. (2010). Tasarımda ilk kavramlar üzerine bütünsel bir model. itüdergisi/a mimarlık, planlama, tasarım 9(1), 3-14.

Uden, J., V., Richardson, K., A., Cilliers, P., (2001). Postmodernism revisited? Complexity science and the study of organisations. Tamara : Journal of Critical Postmodern Organization Science. Las Cruces: 1(3):53-67

Venturi, R., (1991). Mimarlıkta Karmaşıklık ve Çelişki. Çev. Serpil Merzi-Özaloğlu. İstanbul, Türkiye: Şevki Vanlı Mimarlık Vakfı.

Wang, T., (2010). A New Paradigm for Design Studio Education. JADE:173-183

Williams, W., A., Rieger, J., A., (2015). Design History of Design: Complexity, Criticality, and Cultural Competence. racar 40 (2): 15-21

Yurtsever, B. (2017). Mimari Tasarım Eğitiminde Eleştirel Düşünme Becerisinin Tasarım Eğitiminde Rolüne İlişkin Sorgulama. MEGARON, 12(3):385-394

Yücel, S. Aydınlı, S. (2015). Mimarın eğitimi' üzerine spekülatif bir deneme. Erciyes Üniversitesi Fen Bilimleri Enstitüsü Dergisi, 31(1):17-23

Yürekli, İ., Yürekli, F., (2004). Mimari Tasarım Eğitiminde Enformellik. ITÜ Dergisi/a Mimarlık, Planlama, Tasarım, 3(1):53-62.

Zamenopoulos, T., Alexıou, K. (2005). Linking design and complexity: a review. Proceedings of the ECCS 2005 Satellite workshop: Embracing complexity in design. 91-102.

İnternet Kaynakları

Fuard- Luke, A., (2002). A. 'Slow Design'-a paradigm shift in design philosophy? https://carlosfiorentino.files.wordpress.com/2010/03/slow-des.pdf (E.T. 21.04.2018)

https://www.researchgate.net/publication/307545155 Citizen Science and Environmental Edu cation in Italy Possible Developments and the Role of Universities 